


\section{DISCLAIMER}

This report was prepared as an account of work sponsored by an agency of the United States Government. Neither the United States Government nor any agency Thereof, nor any of their employees, makes any warranty, express or implied, or assumes any legal liability or responsibility for the accuracy, completeness, or usefulness of any information, apparatus, product, or process disclosed, or represents that its use would not infringe privately owned rights. Reference herein to any specific commercial product, process, or service by trade name, trademark, manufacturer, or otherwise does not necessarily constitute or imply its endorsement, recommendation, or favoring by the United States Government or any agency thereof. The views and opinions of authors expressed herein do not necessarily state or reflect those of the United States Government or any agency thereof. 


\section{DISCLAIMER}

Portions of this document may be illegible in electronic image products. Images are produced from the best available original document. 


\section{NOTICE}

This report was prepared as an account of work sponsored by the United States Government. Neither the United States nor the United States Atomic Energy Commission, nor any of their employees, nor any of their contractors, subcontractors, or their employees, makes any warranty, cxpress or implied, or assumes any legal liability or respunsibility for the accuracy, completeness or usefulness of any information, apparatus, product or process disclosed, or represents that its use would not infringe privately owned rights.

Printed in the United States of America

Available From the National Technical Information Service, U.3. Departmont of Commerce, 5285 Port Royal Road, Springfield, Virginia 22151.

Price: Microfiche $\$ 1.45$ 1 - to 50-Page Paper Copy $\$ 4.00$ 51 - to 150-Page Paper Copy $\$ 5.45$ 151 - to 325-Page Paper Copy $\$ 7.60$ 
$\mathrm{BDX}-613-1169$

Distribution Category UC-38

\section{AUTOMATIC MACHINE APPLICATION OF SOLID FILM LUBRICANT}

September 1974

Project Leader:

G. P. Miller

Project Team:

R. N. Adams

Technological Spinoff Report

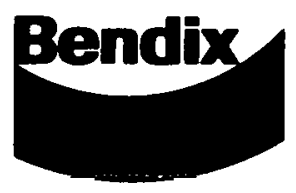

This report was prepared as an account of work sponsored by the United States Government. Neither the United States nor the United States Atomic Energy Commission, nor any of their employees, nor any of their contractors, subcontractors, or their employees, makes any warranty, express or implied, or assumes any legal liahility or responsibility for the accuracy, comproduct or process disclosed information, apparatus, would not infringe privately, or represents that its use would not infringe privately owned riglts. 


\title{
AUTOMATIC MACHINE APPLICATION OF SOLID FILM LUBRICATION
}

BDX-613-1169

September 1974

prepared by G. P. Miller, D/822

Automatic application of solid film lubricant to small precision diameters has been successful using a multi-station machine built at Bendix Kansas City. Future work now being considered would involve machine improvement and an evaluation of factors affecting thickness control and lubricant adhesion.

\author{
THE BENOIX CORPORATION \\ KANSAS CITY DIVISION \\ KANSAS CITY, MISSOURI
}

A prime contractor for the

Atomic Energy Commission

Contract Number AT(29-1)-613 USAEC 


\section{CONTENTS}

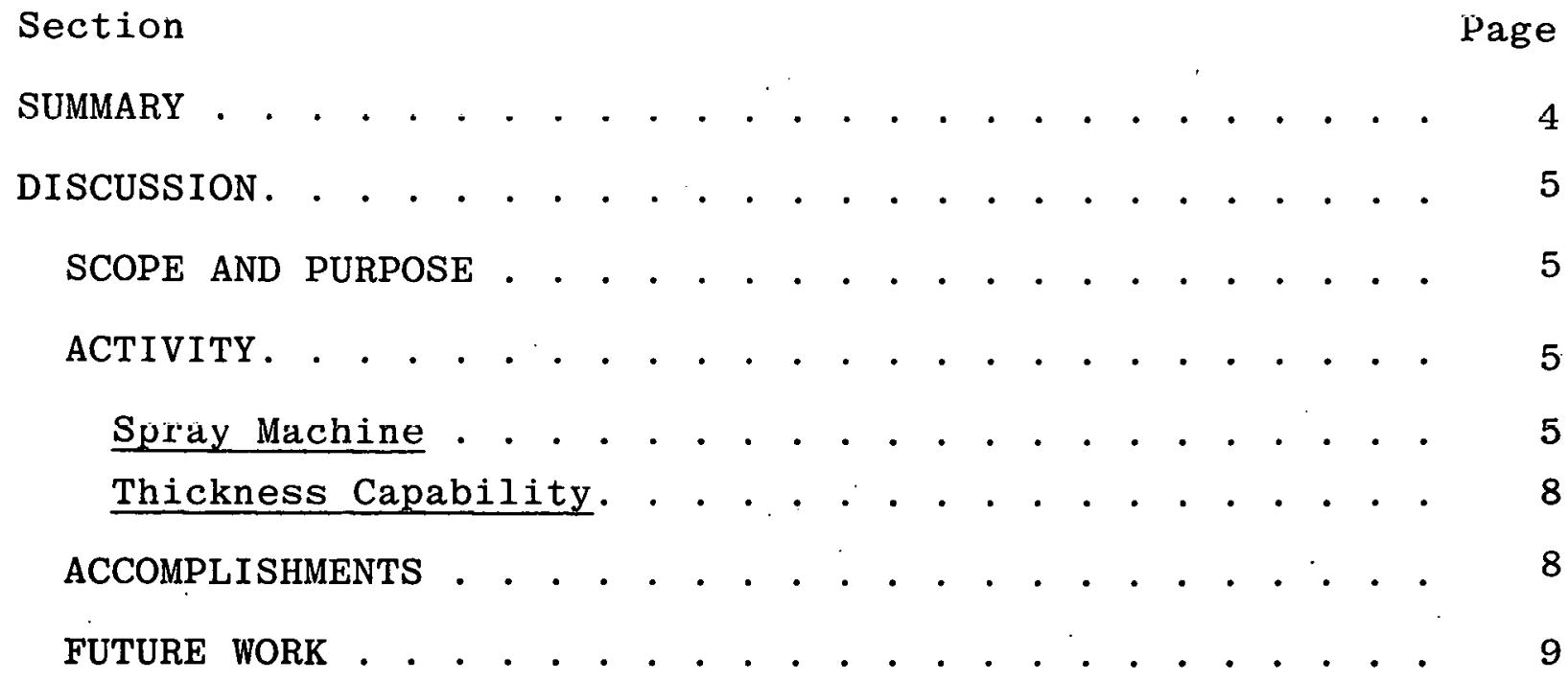

\section{ILLUSTRATIONS}

Figure

Page

1

Automatic Machine Showing Control Panel and Mixing Reservoir (P-83613) . . . . . . . . . 


\section{SUMMARY}

Bendix Kansas City has fabricated and initially evaluated a machine similar to one used by Raymond Engineering to apply lubricants within narrow tolerances to AEC products. The machine employs a turntable with ten stations which rotate independently of the turntable; a control panel; a mixing pot; and a spray nozzle.

Using Electrofilm 4396 diluted with dioxane, 65 runs of ten samples each were coated. The anticipated thickness was achieved on 92.3 percent of the coated samples. The lubricant thickness varied 0.0001 inch $(2.54 \mu \mathrm{m})$ or less on 52 of the 65 runs, and the maximum variation for all runs was $0.00022(5.59 \mu \mathrm{m})$. 


\section{DISCUSSION}

\section{SCOPE AND PURPOSE}

Solid film lubricants at Bendix Kansas City have been hand sprayed in the past. Product tests show that this process produces functional coatings in two thickness ranges.

Thickness control is essential for best wear conditions as well as lubrication, so equipment has been fabricated and tested to evaluate improvements in control from automatic application of the solid film lubricant.

\section{ACT IVITY}

\section{Spray Machine}

An existing machine design used by Raymond Engineering of Middletown, Connecticut was adapted to the Bendix product configuration. The turntable was enlarged to accommodate larger parts, and a pivot was added so parts could be run in a vertical or horizontal position. The machine (Figure 1) consists of four basic components.

- A revolving turntable (Figure 2) with ten stations which rotate independently of the turntable;

- A control panel which controls the number of revolutions made by the turntable;

- A reservoir which holds and agitates the lubricant mixture; and

- A spray gun which applies the lubricant.

The machine is operated on 110 to 120 volts and has a filtered air supply.

Test samples or parts are loaded on the stations using Teflon holding fixtures, and the number of revolutions to meet the required thickness is set on a control panel dial. Depressing the toggle switch on the panel starts the turntable drive motor, and after one revolution the spray gun is automatically activated. When the selected number of revolutions has been completed, the spray gun will turn off and the drive motor will stop.

During the initial runs, the machine did not spray smoothly because of erratic motion in the turntable and the " 0 " ring drive system. In addition, the spray pattern of the Paasche air brush 


\section{0}

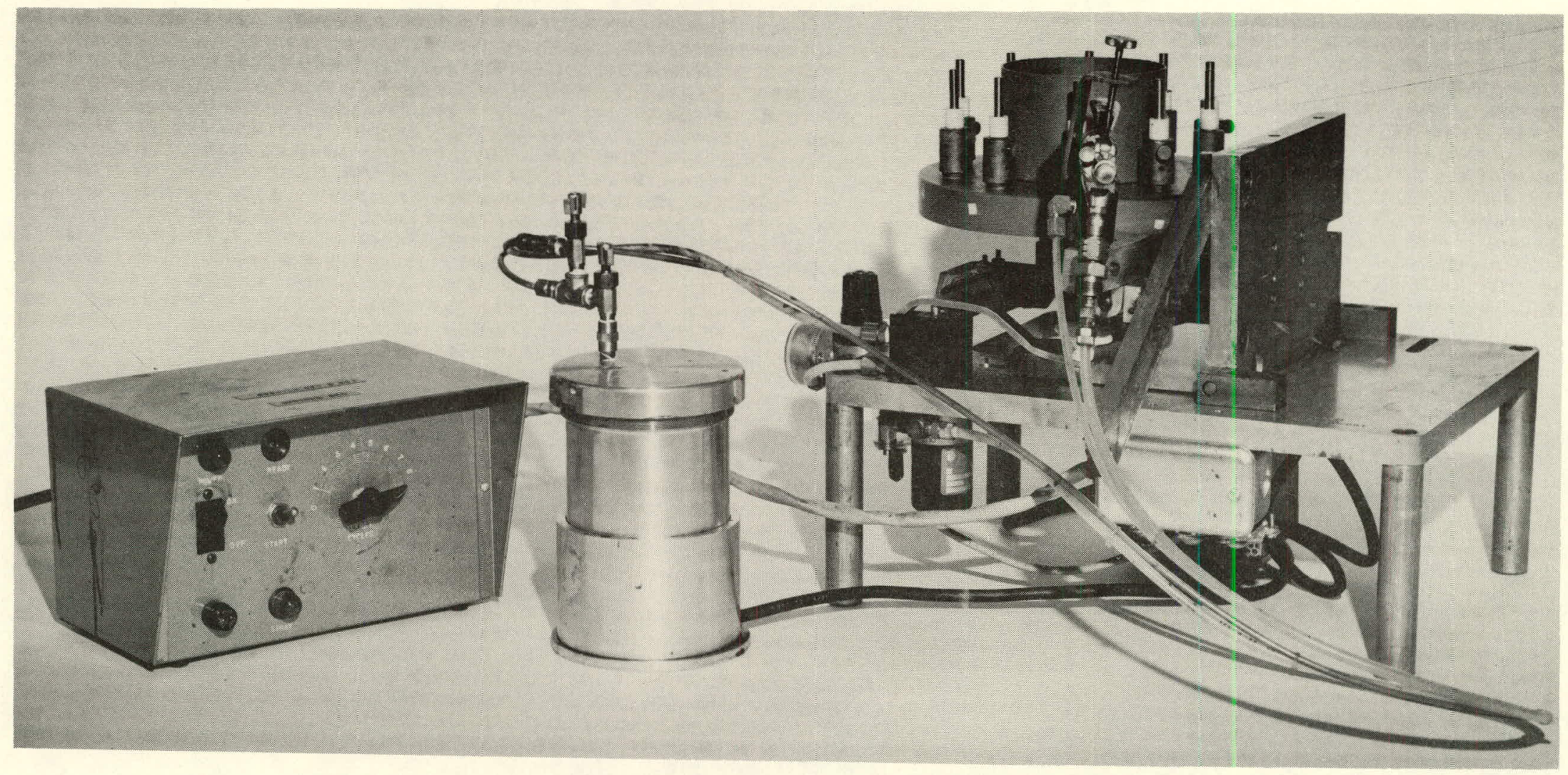

Figure 1. Automatic Machine Showing Control Panel and Mixing Reservoir 


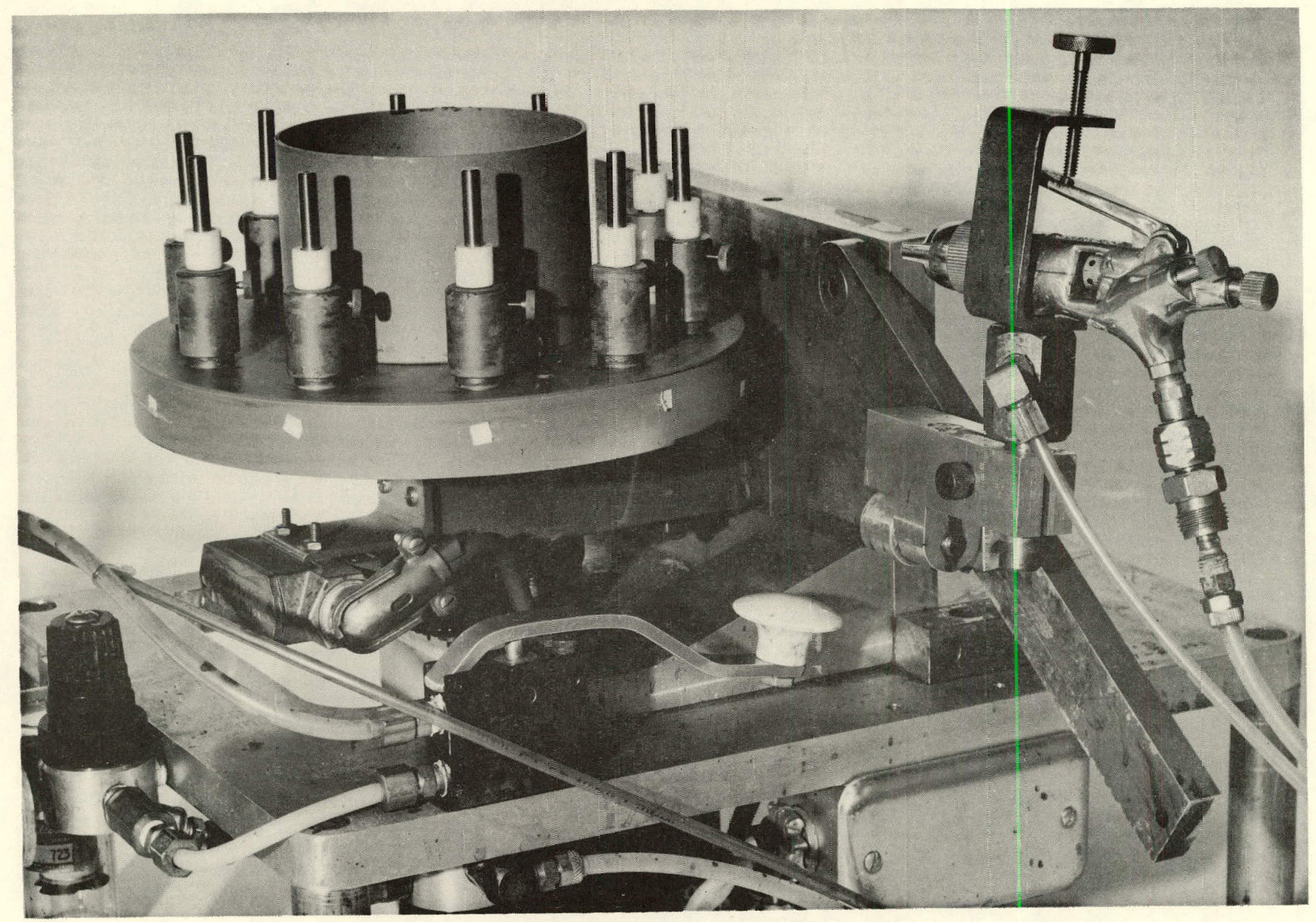

Figure 2. Automatic Machine Showing Turntable and Spray Gun 
nozzle was not large enough and the impeller in the mixing pot did not have sufficient mixing action.

The air brush was replaced with a DeVilbiss P-EGA-502 touch-up gun, a direct gearbelt drive system was added and another impeller was installed in the mixing pot. This type of DeVilbiss gun, currently used in the hand spray application of Electrofilm, has two adjustments, one for spray height and the other for spray quantity.

Thickness Capability

The objective was to determine the machine's capability for applying a dry film lubricant within a selected thickness range. Dowel pins and precision ground pins of 0.250 inch $(6.35 \mathrm{~mm})$, 0.125 inch $(3.175 \mathrm{~mm}), 0.093$ inch $(2.367 \mathrm{~mm}), 0.062$ inch $(1.574 \mathrm{~mm})$, and 0.020 inch $(0.508 \mathrm{~mm})$ inch diameter were coated with Electrofilm 4396 diluted with dioxane to $4: 1$ and $6: 1$ ratios--4:1 for a thickness range of 0.0002 to 0.0005 inch $(5.08$ to $12.7 \mu \mathrm{m})$, and $6: 1$ for a 0.0001 to 0.0003 inch $(2.54$ to $7.62 \mu \mathrm{m})$ thickness range. Ten samples formed a machine load and were run at one time. Measurements were taken before and after coating.

The machine was set up empirically, prior to a run. Three or four pins of known measurements were first coated using a selected set of variables. They were flash dried and remeasured using a bench micrometer at the machine location. If the desired results were not obtained, one or more of the machine variables (cycles, gun air, and fan adjustments) were changed and another three or four pins were coated and measured. This was repeated until desired thickness was obtained.

Fifty-two of the 65 runs had a thickness variation of 0.0001 inch $(2.54 \mu \mathrm{m})$, or less between samples in each run. Thirteen runs had a thickness variation of 0.00011 inch $(2.79 \mu \mathrm{m})$ to 0.00022 inch $(5.59 \mu \mathrm{m})$. The greatest variation occurred in the three runs of 0.020 inch $(0.508 \mathrm{~mm})$ diameter pins. This greater variation was caused by what appeared to be bent pins, possibly occurring during handling or measurement.

When the process was set up to spray 0.0001 to 0.0003 inch $(2.54$ to $7.62 \mu \mathrm{m})$ or 0.0002 to 0.0005 inch $(5.08$ to $12.7 \mu \mathrm{m})$ thick coatings, 516 out of 559 samples ( 92.3 percent): met this thickness.

\section{ACCOMPLISHMENTS}

The Bendix-built machine successfully coated parts with diameters such as shafts, gears, and wheels. In addition, coatings with thickness variations within 0.00022 inch $(5.59 \mu \mathrm{m})$ were applied 
to samples, and the machine demonstrated that it can produce coatings within two thickness ranges.

Deficiencies observed which affect repeatability and uniformity of conting thickness are insufficient agitation of liquid lubricant mixture in the machine's holding pot, and lubricant which dried in the spray gun between runs.

\section{FUTURE WORK}

The benefits that would result from future work and additional testing to improve machine operation are being evaluated.

These proposed alterations would improve the machine operation:

- A solvent flush system for the nozzle to keep it from becoming clogged with dried lubricant;

- A check valve in the supply line to keep the lubricant in the line; and

- Another impeller added to the agitator in the mixing pot to improve agitation and prevent lubricant from settling out of solution.

Additional testing to determine the machine's capability for selected thickness control would use pins of varying diameter and shape; flat surfaces; and piece parts of varying configurations. These variables and their effect on thickness control and adhesion would also be investigated:

- Gun angle;

- Gun nozzle distance;

- Part position (vertical or horizontal);

- Number of cycles;

- Surface preparation;

- Dilution ratio; and

- Ambient conditions. 